\title{
Strategy on climate change adaptation from socio-ecology approach: A philosophical-ethical assessment of Tam Nong district case study
}

\author{
Tuyet Thi Tran - Ngoc Huy Ha - Tuan Hoang Dao - Xuan Thi Tran
}

DOI: 10.18355/XL.2022.15.01.04

\begin{abstract}
Impacts of climate change has been increasing the complexity and seriousness of extreme weather phenomena through changes in the relationship between natural and social systems, especially in low-lying terraced areas with difficulty in water draining in the Mekong River Delta, such as Tam Nong rural district, Dong Thap province, Vietnam, where flooding water is the main factor forming rice cultivation - the main production form of the residents. Nevertheless, the extreme evolvement of climate change, including inundation and acidified soil, is increasingly evident. It affects livelihood strategies in terms of productivity and income under circumstances of offseason rain and abnormally high temperatures. Therefore, active adaptation to climate change requires unified and synchronized solutions based on the outcome of scientific research with a suitable approach. Socio-ecology approach with a focus on analyzing the organic relationship among specific territory systems in combination with dominant factors will provide informative basics to ensure the rationality and harmony in selecting development model following the viewpoint of "respect and utilize nature" in the context of climate change. Such approach both reflects and cultivates socio-ethical responsibility on the side of the local officials as well as the people who are affected by climate change.

Key words: socio-ecology, Tam Nong, Dong Thap, Mekong River Delta, climate change, socio-ethical responsibility
\end{abstract}

\section{Introduction}

The impacts of climate change have contributed to the complexity and seriousness of extreme phenomena through changing relationships between natural and social systems in all regions, areas, and fields of development, especially when development activities dependent on natural resources are increasingly exposed to risks and facing difficulties to maintain and develop (IPCC, 2012; 2014; Butler et al., 2016; WB-ADB, 2018). The uncertainty and unpredictability of climatic factors is a challenge for development activities, especially agricultural production activities in developing countries, in which drought affects the minimum tolerance of plants and people, creates pressure on the economy while people must endure not only droughts but also inundation combined with limited adaptive capacity in terms of institutions, finance, and technology, causing significant losses (Benson \& Clay, 2003; Davies et al., 2013; Butler et al., 2016; Nicholls et al., 2018; Jeetendra et al., 2020). In order to mitigate the impacts of climate change, countries, territories, and communities have proposed many response measures in accordance with the context and priority level from different short-term and long-term approaches mainly focused on building green and low-carbon economic sectors at the national economic scale (UNDP, 2008; Mertz et al., 2009; Niederhafner, 2014); For the community level, it depends on the size and capacity of each household (Klein et al., 2007; Di Falco \& Veronesi, 2013).

However, the obtained results are still limited. The existing solutions may help solve current situations and events but are not viable long term. Communities in developing countries still face many challenges in coping with climate change and natural disasters, which requires a more realistic and systematic strategy toward proactive and interdisciplinary adaptation because climate change impacts do not occur as isolated events. It is a cross-cutting issue and an aggregating industry and territory. Adaptation 
to climate risks is an important aspect to respond to climate change based on effective implementation of integrated, coordinated, and visionary policies to address common tasks in order to avoid mistakes that will bring detrimental impacts in the future (UNDP, 2008; IPCC, 2014; Grosijean et al., 2016; Fankhauser, 2017; Colin et al., 2018; WB, 2016; WB-ADB, 2018). This is a long-term, repetitive process that requires a suitable intervention roadmap, a step-by-step adjustment in the structure to suit the events and impacts based on awareness-raising and adaptive capacity (Fankhauser, 2017; WB, 2016; Millner \& Dietz, 2015). At the same time, it will be cost-effective if it is "integrated" into development processes (UNDP, 2008; FAO, 2012; Mertz et al., 2009; Mimura et al., 2014; Nives \& Aseem, 2018; Watkiss \& Klein, 2019), especially for vulnerable territories such as the Mekong Delta in Vietnam where livelihood activities are predominantly agricultural in nature. Agriculture is the economic sector that is most dependent on climate. Any changes in weather will affect income, living standards of people, and the overall health of the economy. Although the government and the residents have solutions to cope with the impacts of climate change, those are not effective enough, and most are passive. A more general approach is required in adaptive strategic planning (Susmita et al., 2007; Le \& Suppakorn, 2011; Dapice \& Vo, 2012; Chapman \& Darby, 2016; Hoang et al., 2018; USAID/UNDP, 2016). This study supplements and clarifies the impacts of climate change and examines the residents' adaptability to these changes. It employs a com-bination of research results on social ecosystems by analyzing primary and secondary data in Tam Nong district, Dong Thap province, Vietnam. Hence, it builds an appropriate climate change adaptation strategy, in which cultivation, especially rice farming, is considered the main livelihood of the population.

\section{Materials and Methods}

\section{Socio-ecology approach to climate change adaptation}

The socio-ecology approach is an effective tool for territorial development and management by analyzing the reciprocal relationship between humans and nature combined with internal and external factors. It provides a scientific and objective basis for proposing reasonable territorial management solutions, especially in the context of climate change. With a "respect for nature" approach, people are an integral part of nature (Berkes \& Folke, 1998; Chrisna, 2008; Andrew \& Marion, 2011; Petrosillo, Aretano, \& Zurlini, 2015; Colding \& Barthel, 2019). Accordingly, the socio-ecological system is a complex integrated system consisting of social systems, ecosystems with reciprocal relationships with the connotation of the approach characterized by a system. Natural and social factors always exist in a hierarchical interaction relationship in a dynamic equilibrium, ensuring important resources for development in both nature and socio-economy sectors. At the same time, it can adjust continuously to adapt constantly to different approaches suitable to the specificity, characteristics, and development threshold of the research territory (Ostrom, 2009; Epstein, Sandberg, \& Bay-Larsen, 2014). From the above analysis, it can be understood that the socio-ecosystem is a system consisting of two social and ecological components interacting with each other, inseparably on a specific territorial space. Human beings not only exist in a socio-ecosystem but also govern that system (Andrew \& Marion, 2011).

The research results are synthesized, proving the territorial system to be a feasible approach in adaptive governance because it is consistent with the reality of the territory, ensuring fast adaptability and acceptance. Social awareness, especially in the deltas, such as the Mekong River Delta - of climate change issues is identified as a factor that increases the volatility of the region's ecosystems and social systems. Most of the impacts are extreme, leading to a decline in the resilience of the ecosystem with ever-increasing damage, especially in the condition when management capacity, as

XLinguae, Volume 15 Issue 1, January 2022, ISSN 1337-8384, eISSN 2453-711X 
well as the coping capacity of authorities, communities, and people, are limited and depend on natural resources - ecology (Epstein, Sandberg, \& Bay-Larsen, 2014; Beichler, 2017; Gorddard et al., 2016; Juan et al., 2020).

With the flexibility of the socio-ecology approach based on the results of systematic research, its inter-disciplinary nature will ensure the provision of scientific information as a basis for recommendations appropriate to regional development policy, ensuring the load-bearing capacity of nature, management capacity, knowledge, cultural identity and feasibility in the implementation process, while solving conflicts in the declaration, exploiting and using of resources. This proves to be especially suitable for developing policies to adapt to climate change based on proactive adaptation, promoting potential advantages, transforming challenges into opportunities for development (McGinnis \& Ostrom, 2014; Nicholls et al., 2018; Garmestani et al., 2019). Respecting nature and making a wise use of it becomes more viable when choosing the adaptive model, integrating human activities and social structure into the system to ensure harmony in adaptation and development, as these are expected to enhance territorial competitiveness combined with strengthening human adaptive capacity and natural systems to protect and improve the quality of life, ensure security and sustainable development of the territory through improving ecological and rational social capacities (Ostrom, 2009; Michael et al., 2014; Petrosillo, Aretano, \& Zurlini, 2015; Juanet al., 2020).

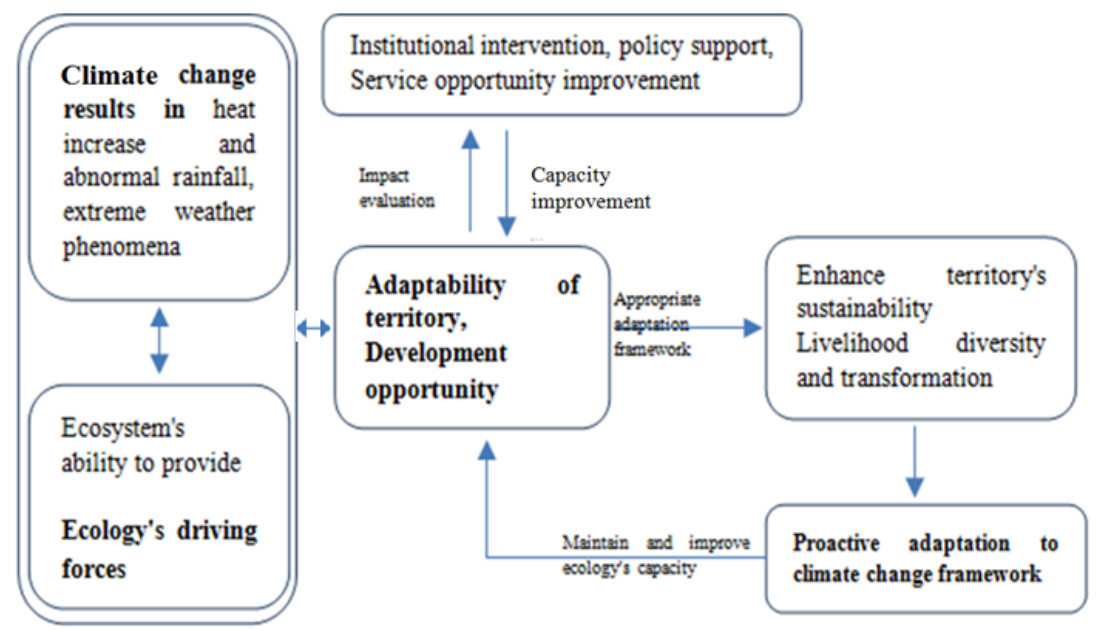

Figure 1. Model on proactive adaptation to climate change from socio-ecology approach (Source: Research results of the authors (2021)).

Based on the model of proactive climate change adaptation from the socio-ecological approach, the territory's basic resources with factors that have a mutual relationship affects the choice of adaptive solutions and ensures harmony with the ecosystems and capacities of the society. These resources help us take advantage of the self-regulation and self-adaptive characteristics in the resilience of the ecosystem and ensure good responsiveness. The development needs of the human/ social system, especially in the delta area, are influenced not only by natural laws but also by transitional socioeconomic laws. The model above (Figure 1) shows that when climate change increases its impact on the delta region with the main manifestations of temperature, irregular rainfall, and extreme weather events will affect the dynamics of the 
ecosystem services. At the same time, the ecosystem also has adverse reactions to these impacts. The reactive capacity depends on the health of the ecosystem.

The resulting impacts of climate change and ecosystems affect territorial resources and development opportunities. It is easy to conduct an impact assessment using an integrated approach based on measuring differences in capital sources of adaptive capacity. The scientific results obtained are practical. They propose strategic solutions to strengthen capacities through an appropriate active adaptive framework. This solution framework is the integration of many factors to actively adapt to climate change. At the same time, the sustainability of development strategies (social systems) addressing the impacts of climate change is also the basis for maintaining or increasing the adaptive and load-bearing capacity of ecosystems.

\section{Area of investigation}

Dong Thap province, Vietnam, located upstream of the Mekong Delta region, is considered one of the localities severely affected by extreme weather events related to climate change, especially inundation with the highest risk in the region (Bangalore, Smith, \& Veldkamp, 2016; Dang, Leonardelli, \& Dipierri, 2016; WB, 2016; Bui et al., 2018). In recent years, the impacts of climate change have become more serious, affecting territorial development. Floods are erratic with complicated developments. They tend to decrease, changing natural characteristics of flood time, which leads to a decrease in the alluvium in rivers, an increase in alum contamination, and development of pests and diseases (Vietnam-Netherlands Mekong Delta Masterplan Project, 2013; Dong Thap Provincial People's Committee, 2019b). According to the Dong Thap Climate Change Action Plan, if the sea level rise is combined with floodwater caused by climate change, it will cause flooding and serious damage to the area. It will be difficult for people to protect the incoming rice crop and infrastructure, control floods in the region, as well as make full use of floodwater re-sources to develop livelihoods and improve living standards (Dong Thap Provincial People's Committee, 2019b; Ministry of Natural Resource and Environment, 2019a; Ministry of Natural Resource and Environment, 2019b).

\begin{tabular}{|c|c|c|c|c|c|c|c|}
\hline \multirow[b]{2}{*}{ Year } & \multicolumn{3}{|c|}{ Chau Doc } & \multicolumn{3}{|c|}{ Tan Chau } & \multirow{2}{*}{$\begin{array}{l}\text { Total } \\
\text { Qmax } \\
\left(\mathrm{m}^{3 / s}\right)\end{array}$} \\
\hline & $\begin{array}{c}\text { Hmax } \\
(\mathrm{cm})\end{array}$ & $\begin{array}{l}\text { Qmax } \\
\left(\mathrm{m}^{3} / \mathrm{s}\right)\end{array}$ & Daily & $\begin{array}{c}\text { Hmax } \\
(\mathrm{cm})\end{array}$ & $\begin{array}{l}\text { Qmax } \\
\left(\mathrm{m}^{3 /} / \mathrm{s}\right)\end{array}$ & Daily & \\
\hline 2000 & 490 & 7,660 & $22 / \mathrm{IX}$ & 560 & 25,500 & 25/IX & 33,160 \\
\hline 2005 & 390 & 6,560 & 18/LX & 435 & 21,990 & 27/IX & 28,550 \\
\hline 2010 & 278 & 5,560 & $23 / X$ & 320 & 19,100 & $23 / X$ & 24,660 \\
\hline 2015 & 235 & 4,570 & 15/VIII & 255 & & & \\
\hline 2016 & 284 & 5,030 & $17 / X$ & 307 & 19,700 & $15 / x$ & 24,730 \\
\hline 2017 & 309 & 5,700 & $8 / x$ & 343 & 22,000 & $31 / \mathrm{VII}$ & 27,700 \\
\hline 2018 & 372 & 5,540 & $15 / x$ & 423 & 20,890 & $25 / X$ & \\
\hline 2019 & & & & 363 & & 17/IX & \\
\hline 2020 & 400 & 6,870 & 29/IX & 450 & 22,000 & $4 / \mathrm{X}$ & 28,870 \\
\hline
\end{tabular}

Table 1. Water level (Hmax) and flood peak (Qmax) at the measuring points at the upstream Chau Doc and Tan Chau (Source: Research results of the authors (2021)).

Tam Nong district is located in the north of Dong Thap province with a natural area of $459 \mathrm{sq} \mathrm{km}$ and a population of 99,995 people. It includes Tram Chim National Park in

XLinguae, Volume 15 Issue 1, January 2022, ISSN 1337-8384, eISSN 2453-711X 
the 2000 Ramsar area of the world with wide coverage. Tien River flows through the gills and overflows into the field which is convenient for rice cultivation, crops, and aquaculture. Tam Nong district was selected in the study because rice cultivation is the main livelihood here. Rice production is about 6.09 tons per ha. Extreme developments of climate change in the whole province are increasingly evident, affecting livelihood strategies of the population, especially inundation, acidic soil, and the spread of acidic water in the low-lying areas. When combined with off-season rains, abnormally high temperatures affect productivity and income (Interviewee 1,2).

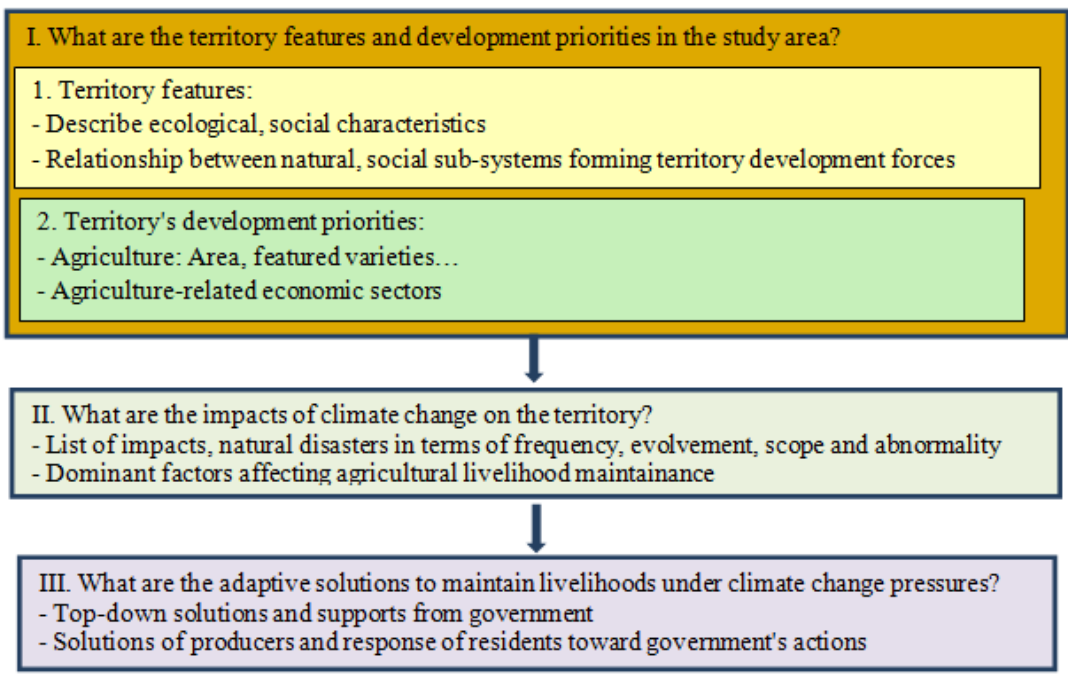

Figure 2. Research Design (Source: Research results of the authors (2021))

Data collection and analysis were conducted through secondary data review and investigation survey, which combined ten in-depth interviews, group discussions with 42 people (30 people and 12 local officials) in January 2021. The interviews included regulators (province, district, commune) and people involved in the livelihood activities of rice cultivation (Table 2). 


\begin{tabular}{|c|c|c|c|}
\hline $\begin{array}{l}\text { Interview } \\
\text { number }\end{array}$ & Interviewec & Location & $\begin{array}{c}\text { Number of } \\
\text { people } \\
\text { interviewed }\end{array}$ \\
\hline 1 & $\begin{array}{l}\text { Dong Thap province's province-level } \\
\text { organizations: Department of Natural Resource and } \\
\text { Environment ( } 1 \text { male), Department of Planning and } \\
\text { Investment ( } 3 \text { male), Department of Labor, Invalids } \\
\text { and Social Affairs (1 male), Department of } \\
\text { Agriculture and Rural Development (1 male, } 1 \\
\text { female) }\end{array}$ & $\begin{array}{c}\text { Cao Lanh } \\
\text { City }\end{array}$ & 7 \\
\hline 2 & $\begin{array}{l}\text { Tam Nong district's district-level organizations: } \\
\text { Department of Agriculture and Rural Development (1 } \\
\text { male, } 1 \text { female); Department of Natural Resource and } \\
\text { Environment ( } 1 \text { male); Phu Tho People's Committee } \\
\text { ( } 2 \text { male); Tram Chim Town People's Committee (1 } \\
\text { male) }\end{array}$ & $\begin{array}{r}\text { Trапı Chimı } \\
\text { Tow } \\
\text { n }\end{array}$ & 5 \\
\hline 3 & Farmers ( 5 male) & $\begin{array}{l}\text { Phu Tho } \\
\text { Commune }\end{array}$ & 5 \\
\hline 4 & Fanters ( 3 male; 2 fenıale) & $\begin{array}{l}\text { Phu Tho } \\
\text { Commune }\end{array}$ & 5 \\
\hline 5 & Farmers ( 4 male; 1 female) & $\begin{array}{l}\text { Phu The } \\
\text { Commune }\end{array}$ & 5 \\
\hline 6 & Farmers ( 1 male, 2 female) & $\begin{array}{l}\text { Phu Tho } \\
\text { Commune }\end{array}$ & 3 \\
\hline 7 & Farmers ( 3 male, 1 female) & $\begin{array}{l}\text { Phu Tho } \\
\text { Commune }\end{array}$ & 4 \\
\hline 8 & Farmers ( 1 male, 2 female) & $\begin{array}{l}\text { Tram Chim } \\
\text { Town }\end{array}$ & 3 \\
\hline 9 & Farmers (2 male) & $\begin{array}{l}\text { Tram Chim } \\
\text { Town }\end{array}$ & 2 \\
\hline 10 & Farmers ( 2 male, 1 female) & $\begin{array}{l}\text { Tram Chim } \\
\text { Town }\end{array}$ & 3 \\
\hline
\end{tabular}

Table 1. Interviews Information (Source: Research results of the authors (2021)).

\section{Results}

\section{Territory features and development priorities}

Territorial characteristics are determined based on specific factors of natural conditions and natural resources, interacting with each other to create natural resources for territorial development. We combine these with social factors identified based on cultural and social characteristics expressed through the dominant mode of production, reflecting the mutual relationship between ecological and social components. This becomes the basis for forming integrated resources for territorial development (Tran, 2015; Tran et al., 2021; Nguyen, Ha, \& Tran, 2020). 
The study area is formed from low ground. Ancient alluvial is very shallow, a few meters from the ground or exposed as mounds with an average topographic elevation of about $1-2.0 \mathrm{~m}$ above the sea level, gradually lower in the Northwest - Southeast direction (Institute of Water Resource Planning, 2016; Institute of Southern Construction Planning, 2014; Interview 1, 9). The topographic morphology creates favorable conditions for flood drainage to the central low-lying area with low terrain of $0.4-0.5 \mathrm{~m}$ combined with soil, including 03 groups of alum soils in the southeast, alluvial soil, and sandy soil. In terms of flood capacity, mainly due to the impact of floods from upstream combined with the phenomenon of high tide, water drainage into the sea becomes more difficult. Most areas have flood time from 2 - 3 months per year. The amount of water on the surface is mainly used for ecological functions, regulating floods, and maintaining the balance of wetland ecosystems; however, it is not enough to meet the needs of agricultural production in the dry season. In addition, water is contaminated with alum and polluted with organic waste and microorganisms, so it cannot be utilized for domestic purposes (Interviewee 1, 2, 5,6). The characteristics of ecological funds combined with investment and development of the irrigation system have formed a model of exploitation and use of specific territories with dominant agricultural livelihoods, in which rice cultivation is considered the strength and development priority strategy of the government and the population. The area of rice cultivation is over 30 thousand hectares. Two main crops are planted. Winter-spring starts from December to the end of February of the following year. After harvesting, the land has a break for four weeks and then starts the Summer-Autumn crop from early April to mid-July. The average yield is 62 quintals per ha, the total output 375,000 tons, and the total value of agriculture reaches 4,687 billion VND. Regarding the rice variety structure, the production area of highquality rice varieties reaches nearly 70\%, sticky rice 30\%; IR 50404 accounted for $1.6 \%$, and other rice varieties $3.8 \%$. Cultivated fields are usually surrounded by dykes with a height of about $2 \mathrm{~m}$ above the field surface, allowing floodwater to overflow after the Summer-Autumn crop. The flood discharge carried out in late November has contributed to improving the fields, adjusting seasonal schedules to limit soil degradation, and destroying pathogens stored in the soil to limit production investment costs of farmers. In addition, the socio-economic activities in the area are associated with wet rice cultivation, such as: color rice, shrimp rice, processing of agricultural products and foodstuffs, trade, and services. Tourism development associated with Tram Chim National Park - Ramsar area is of international importance (7,500 ha). It contains a typical miniature model of Dong Thap Muoi, with a diverse ecosystem, typical of the 6-month region inundation months, and forms the habitat of the rare and globally protected red-headed crane (Interviewee 2).

Based on socio-ecological factors (irrigation), the study area can be divided into 03 subdivisions to meet the requirements of rice development, in which: soil and time of flooding in the year are multiplied and become the dominant factor. Other factors in terms of topography, qualifications, and experience in territorial exploitation are relatively homogeneous. Specifically: the subdivision of deep acidified soil, flood time of 2-3 months $(17,879.45 \mathrm{ha})$; shallow acidified soils, flood time of 2-3 months (6,063.05 ha); alluvial soil, not flooded (4,454.72 ha); alluvial soil, flood time of 2-3 months $(11,490,17 \mathrm{ha})$. Shrimp rice models are often developed in shallow acidified soils. Deep acidified soil and alluvial soil develop rice-cropping patterns.

\section{Impacts of climate change}

Climate change is causing serious impacts on the development process with un-usual and unpredictable developments in floods and droughts. The water level tends to increase, causing inundation in some areas. According to the medium emission scenario, the water levels in 2020, 2050, and 2100 are forecasted to increase by $11 ; 20$ and $48 \mathrm{~cm}$; the area will be inundated with $0.5-2.3 \mathrm{~m}$ depth respectively; $0.8-3.1 \mathrm{~m}$; 
1.2-3.7m. In addition, Tram Chim National Park and acid sulfate land were affected by drought. Therefore, the area of rice cultivation will be narrowed, and productivity will be affected by climate change.

The temperature by 2100 can increase from 0.7 to $1.80 \mathrm{C}$ (RCP4.5 scenario) and 0.93.30C (RCP8.5 scenario). Rainfall by the year 2100 will also increase. The estimated annual rainfall increase will be from $10.0-17.2 \%$ (RCP4.5 scenario) and 11.0-23.7\% (RCP8.5 scenario). During the dry season, rainfall tends to decrease by $3 \% \div 15 \%$. Droughts are more severe due to the trend of declining rainfall in the dry season (Ministry of Natural Resource and Environment, 2019b). In recent years, temperatures have increased along with the local heavy rains. Also, off-season rains have increased in frequency and quantity (Result of 10 interviewees). Temperature increases and abnormal changes will increase the development of pests and diseases and increase production costs, which will inadvertently affect people's income. In fact, with blast disease and aphids developed, people have to double the cost to overcome these challenges (in 2015, they only needed to spray 1-2 times/crop; in 2020, 3-4 times per crop) (Interview 3, 7, 8). Mice also increase damage to rice. People must take measures to kill rats, using mainly chemical pesticides (Interviewee 3, 4). At the same time, the increased temperature will make aquaculture in the area less efficient if the water level does not meet the maintenance of a stable habitat (Interviewee 1,2,5).

In addition, if the sea level rise and floodwater caused by climate change cause flooding and serious damage to the area, it will be difficult for people to protect the summer rice crop and infrastructure and control floods in the region. Also, it will become challenging to make full use of floodwater resources to develop livelihoods and improve living standards. Therefore, dredging drainage canals will help to drain floodwater better during the flood season. In addition, improvements to low embankments, spillways, sluices and pumping stations, flood water regulation, and storage will help develop livelihoods for local people during the flood season (Interview 1,2).

Water sources and floods from the upper Mekong River are the decisive factors affecting the sustainability of agricultural livelihoods. However, abnormal changes in both flood volume and time combined with climatic factors (temperature, precipitation) are not conducive to making a sustainable production environment. Extreme weather phenomena appear with more frequency (drought, tornado, hail). In addition, the resources for forecasting and investment, as well as the response of the government and people, are limited, so production still depends mainly on weather factors and the amount of water from upstream. Production costs increase, resulting in a lower income (investment costs are about 652-870 USD /ha/crop) (Results of 8 interviews with people) for the majority of the population. People are relatively passive in production. This is because the weather determines much of the agricultural outcome: if the weather is stable, the season is stable, and the income will be stable. But if the changes are too abrupt, people lose their crops and their livelihoods. Compared to previous years, the harvested output in 2015 decreased by one-half on average (from $8,000-8,500 \mathrm{~kg} / \mathrm{ha}$ down to $4,000 \mathrm{~kg} / \mathrm{ha}$ ). Even if the selling price has increased, the increase was only about USD $0.04-0.06 / \mathrm{kg}$; from $0.2 \mathrm{USD} / \mathrm{kg}$ to 0.26 USD / kg (Interviewee 3.5.8).

Climate change affects the volatility of income, so many people have migrated to other localities to seek livelihoods, supplementing the household's income. The characteristics of the labor migrants are: (1) young age, (2) physically fit, (3) able to apply scientific and technological advances to production. Most of the people involved in wet rice cultivation are middle-aged people. Women cannot earn income from other livelihoods, so they focus on agriculture. Their agricultural methods are based on experience, mainly learning from each other, except for the planting calendar (Interviewee 2, 3, 6,7), which constitutes a disadvantage when they seek

XLinguae, Volume 15 Issue 1, January 2022, ISSN 1337-8384, eISSN 2453-711X 
recommendations from the local government. In addition, they do not have enough capital to change production methods, especially varieties of crops. New varieties are likely to adapt to a changing environment but at a higher price. The plants' tolerance to changing weather is limited, making them vulnerable to damage. Moreover, the production scale is mainly that of households, which is too small. As individual households do not participate in linking production, they are often pressed by private traders to sell at a lower price. Selling prices are not stable, with little technical support and production capital. The majority of the production is in the form of "selfproduced, self-consumed," i.e., subsistence farming, which is slow to innovate. Therefore, production has not closely followed market demand (Result of 10 interviewees). In addition, the shift of crop structure from rice production to crop production is slow, prices are not stable, infrastructure and irrigation systems cannot meet production requirements, and mechanization has many limitations. The profit is not attractive (Interviewee 1,2).

Drought and excessive rain had the greatest impact on the landscape and existing water resources among natural disasters. In the winter-spring crop 2020-2021, the seeding time due to abnormal rain caused some damaged areas to sow again, which amounted to 50 ha in PhuTho commune (Interviewee 2). There is a risk of water shortage to remove alum and kill pests for agricultural production. Along with environmental pollution, serious ecological imbalance, land subsidence, and decline in groundwater level, it is difficult to ensure productivity, quality, and cost reduction (Interviewee 1,2).

\section{Adaptive solutions to maintaining agricultural livelihoods under climate change pressures}

Local government's solutions to increase adaptability are at the forefront of current deliberations. Construction measures revolved around mobilizing resources for investment in infrastructure, especially irrigation systems, building irrigation canals and dykes to protect against floods around cultivated areas, making an important contribution to farming oriented mostly on two main crops with short-term rice. In addition, the government connected small irrigation systems into larger systems to ensure water levels stability; developed intra-field irrigation systems in service of large sample fields combined with small and medium pump stations to proactively raise production; im-proved irrigation efficiency; controlled the spread of epidemics; and took measures to gradually improve the quality of agricultural products. Every year, the examined area is funded by the provincial government for the construction and upgrading of infra-structure, including irrigation works (Interviewee 1, 2). Specifically: in the period from 2015-2020, Tram Chim town has been supported to upgrade dykes to overcome floods to serve the transformation of crop structure into urban agricultural areas with a total budget of about 58,696 USD; the local officials organized dredging in the field with a total length of $11,404 \mathrm{~m}, 30,782$ USD (Interviewee 2)

ODA capital sources have been used to improve irrigation infrastructure as part of a concerted effort to implement new development programs aimed at increased and sustainable production. For example, under the integrated climate resilience project, the sub-project was dedicated to improving flood drainage capacity and developing sustainable, climate-resilient livelihoods for Dong Thap Muoi (northern districts and towns of Dong Thap province). The project entitled "Sustainable Livelihoods in the Mekong River Delta" (MD-ICRSL) used the World Bank's loans to build irrigation, water supply, and drainage works to meet current production requirements, to change production structure suitable for floodplain areas to stabilize livelihoods, improve lives for the community, and contribute to the sustainable development of the region in the context of climate change according to the principle of 'no-regret' investment in the future. The project helped people apply advanced technology to rice production, 
in-crease profits by applying sustainable farming techniques, and link rice value chains (Dong Thap Provincial People's Committee, 2019a; Interviewee 1, 2).

Non-structural measures included efforts to make full use of water resources in the first months of the rainy season and the beginning of the dry season in combination with solutions to improve land-use efficiency in the flood season and raise awareness of the community to adapt to the impacts of climate change proactively. People needed to be instructed regarding water environment protection, rational use of fertilizers and pesticides, and collection of agricultural waste. Institutions and policies aimed at developing reasonable land-use planning and livelihood solutions (giving priority to vulnerable groups) needed to be established. At the same time, the building of operational procedures and warning information systems strengthened management's capacity to deal with corresponding challenges.

\section{Residents' adaptive solutions}

Through their experience living with floods, people have accumulated prediction and adaptation knowledge, such as observing the changes in water color or the flood cycle (excessive flood levels every three years). However, in recent years, the prevailing weather patterns irregularities have made the cumulative experience of the people less reliable. (Interviewee 3, 7, 8). Up until recently, the folk forecasting models had hardly been taken into account in production but were instead replaced by information from the communal authorities. Farmers adhered to the time of sowing and planting according to the recommended seasonal schedule. However, other methods of care and selection of varieties are still mainly based on experience or under the instructions of places where materials are sold, such as seeds, fertilizers, and pesticides. These communities seldom follow government guidance. Therefore, the abuse of pesticides and chemical fertilizers is increasing. As such, it is difficult to control, causing environmental pollution and reduction of product quality (Interviewee 3, 4, 5, 6, 8). Rice varieties are also of unknown origin, with a low resistance to diseases. In addition, people often choose short-term rice varieties to ensure more crop safety, especially when a few households cultivate the third crop (Autumn-Winter). In Autumn-Winter season, it is recommended to leave the soil to rest and to wash the alum (Interviewee 4, 8). Some households apply scientific and technical advances to their production, such as eco-nomically efficient irrigation processes or change of irrigation schedule, and participate in the crop rotation model on rice land (Interviewee 7.10).

\section{Discussion \\ Difficulties in implementing climate change adaptation models}

Climate change combined with water depletion in upstream areas is increasing the complexity and severity of impacts through changing relationships between natural systems and social systems. It is considered as one of the main limiting factors in territorial development. Still, currently, the response to climate change is being managed according to administrative territory, not yet considering the issue of interregional climate change resilience with a focus on engineering solutions. Financial capital investment is spread across a variety of budget sources. Meanwhile, the ability to mobilize financial resources from the community is still limited. Therefore, the flood-adaptive works are not sufficient, especially in the context of increasingly unusual and unpredictable climate change-related events. The existing response scenarios are no longer compatible, resulting in processes that are not conducive to achieving the stated goal. Along with that, the amount of alluvium on the Tien and Hau rivers has decreased significantly. The area of soil contaminated with alum tends to increase, especially in Dong Thap Muoi low-lying area.

XLinguae, Volume 15 Issue 1, January 2022, ISSN 1337-8384, eISSN 2453-711X 


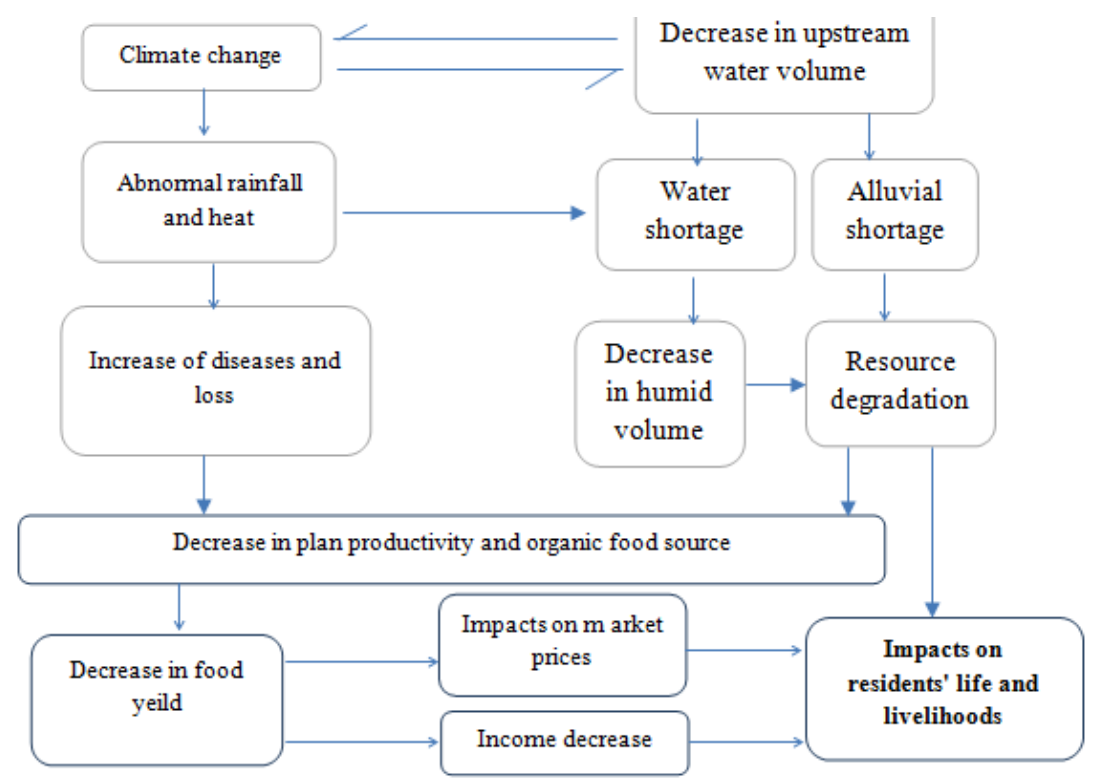

Figure 3. Impacts of climate change on residents' life and livelihoods (Source: Research results of the authors (2021)).

The models to encourage the development of local governments in the direction of minimizing waste and protecting the environment are difficult to deploy on a large scale; they are more readily implemented in the pilot model, however. For example, the model of applying science and technology towards organic, environmental protection, using organic fertilizers and biological drugs, only stops at 150 hectares. The government has encouraged establishing 31 cooperatives to link production and establish a basis to mobilize resources to implement synchronous and unified solutions proactively. However, most of the cooperatives only carry out irrigation pumping service, not upholding the core role in gathering, operating production, and business to bring benefits to members (Interviewee 2).

People who are aware of the role of nature-based farming readily adopt organic farming to protect the production environment. However, due to limited resources, transition decisions are influenced significantly (Interviewee 3.5). Most farmers do not trust businesses. The linkage method has not been agreed upon. Moreover, new farming techniques require certain qualifications, but in reality, the people engaged in production in the studied area are less likely to change off-farm jobs or to migrate to another locality seeking more stable and higher income or cultivating primarily to hold land title. Thus there is no incentive to convert to or participate in governmentencouraged models (Interviewee 3,5, 8,9, 10). Income from agricultural production is low, about 10 - 15 million VND per ha (the average cultivated area is 2 ha per household), so there is not enough financial resources to synchronously invest in irrigation systems, ensuring varieties' quality, and using organic fertilizers; therefore, the immediate solution is to increase the use of rapidly effective, chemical products to cope with epidemics and predators (Results of 8 interviews with people). Selfconscious households must diversify their livelihoods and different forms of income to sustain their lives. However, the main method of implementation is to migrate to localities with developed industrial activities to seek employment which results in neglecting the local potentials. Post-harvest processing activities have not been developed and thus cannot attract surplus labor (Interviewee 3, 4, 9). 


\section{The characteristics of the socio-ecology approach}

The socio-ecology approach is the analysis and integration of different factors to find the dominant factor combined with territorial capacity. According to the social ecology approach, the proposed solutions from the results of territorial research will ensure scientific and practical outcomes with scenarios to be deployed in stages, helping managers make possible decisions. However, applying the above approach requires quite large data sources for research in all activities of the territory. The solution is only suitable when there are accurate data sources and clearly identified resources. At the same time, it requires different interdisciplinary research teams to choose specific features and to identify bottlenecks and limitations, all of which constitute the basis for determining integrated solutions suitable for the context within a given region. Some solutions are based on the social ecology approach.

Based on the division of different subdivisions (Figure 2) combined with the analysis results from the status of the impact of climate change on wet rice cultivation, it is possible to determine the appropriate level for each type. The use of resources in accordance with ecological funds and social resources ensures the harmony between inherent resources in natural resources, people, and the environment and external support resources aimed to improve high response capacity.

Emphasis is placed on general orientation for the subdivisions to use resources efficiently, adapt to climate change, and develop diversified types of livelihoods and farming systems in harmony with nature, which means dominant factors of the area are based on flood source and soil type. At the same time, priority should be given to linking production in the direction of accumulating land, forming a specialized area. Then there will be uniform conditions for investment in scientific and technical advances to develop quality agricultural products according to the linkage model, gradually changing the thinking from "agricultural production" to "agricultural economy." People will thus be motivated to take advantage of connecting with chains of agricultural products available in the region to develop brands, increase product value, create jobs on the spot, targeting especially young and qualified people.

\section{Conclusions}

There is a measurable increase in the impact of climate on the studied area. Where the topography is low and difficult to drain water, the livelihood activities are directly affected by the annual floodwater volume. Therefore, to proactively adapt to climate change, it is necessary to have appropriate solutions based on a systematic and territorial approach, especially in the context of complex and volatile climate change conditions to ensure the flexibility of the local people and increase initiative in responding to the current challenges. At the same time, due to the limited capacity and resources of the territory, a solution related to managing water resources in view of the changed climate conditions is considered optimal. Such solution will likely arise from employing the so-called socio-ecological approach. Based on our research data, the socio-ecological approach is effective in territorial management as it implements a com-bination of the natural and social approaches to find out the differences and dominant factors affecting the relationship between human and nature using the available methods of resource exploitation. It uses the principle of complying with the threshold of socio-ecological resilience to allow people's livelihood activities, while preventing the economy to destroy the environment and run out of resources. Such an approach exemplifies the most viable course of action in compliance with the principle of socio-ethical and environmental responsibility.

XLinguae, Volume 15 Issue 1, January 2022, ISSN 1337-8384, eISSN 2453-711X 


\section{Acknowledgments}

The research on which this paper is based is a result of the scientific research project "Study to propose policy framework for proactive adaptation to climate change in Mekong River Delta from socio-ecology approach" funded by NAFOSTED (Principal investigator: Dr. Tuyet Thi Tran). This research was funded by NAFOSTED Vietnam's National Foundation for Science and Technology Development, grand number 507.01-2019.301.

\section{Bibliographic references}

Andrew, H. and G. Marion (2011). "A management perspective on social ecological systems: A generic system model and its application to a case study from Peru," Human Ecology Review, 18(1), 1-18.

Bangalore, M. S., Smith, A. and T. Veldkamp (2016). Exposure to floods, climate change and poverty in Vietnam. Policy research working paper 7765. New York: The World Bank.

Beichler, S.A. (2017). Understanding Social-Ecological Systems Under Climate Change - Exploring the Ecosystem Service Concept Towards an Integrated Vulnerability Assessment [Dissertation]. Hamburg: Hafencity Universitat.

Benson, C. and E. Clay. (2003). Economic and Financial Impacts of Natural Disasters: An Assessment of Their Effects and Options for Mitigation: Synthesis Report, Final Report. London, UK: DFID.

Berkes, F. and C. Folke (eds.) (1998). Linking Social and Ecological Systems. Cambridge, UK: Cambridge Univ Press.

Bui, B.B., Nguyen, H.S., Bui, T.Y., Nguyen, V.B., Nguyen, D.T., Le, T.T., Trinh Q.T., To, Q.T., Labios, R. and L. Sebastian. (2018). Adaptation measures for rice-based farming systems in the Mekong Delta provinces in the context of climate change. Evaluation report 245. CCAFS. Wageningen, Netherland: Research program of CGIAR on Climate change, Agriculture and Food Security.

Butler, J.R.A., Suadnya, W., Yanuartati, Y., Meharg, S., Wise, R.M., Sutaryono, Y., and Duggan, K. (2016). "Priming adaptation pathways through adaptive comanagement: Design and evaluation for developing countries." Journal of Climate Risk Management, 12(12), 1-16.

Chapman, A. and S. Darby (2016). "Evaluating sustainable adaptation strategies for vulnerable mega-deltas using system dynamics modelling: Rice agriculture in the Mekong Delta's An Giang Province, Vietnam," Science of the Total Environment, 559(1), 326-338.

Chrisna, D.P. (2008). Understanding cities as social-ecological systems. World Sustainable Building Conference - SB'08, Melbourne, Australia, 21 - 25 September. Australia: CSIRO - Australia's national research organization.

Colding, J. and S. Barthel (2019). "Exploring the social-ecological systems discourse 20 years later," Ecology and Society, 24(1), 1-11. https://doi.org/10.5751/ES-10598240102.

Colin, C., Xiaomeng, C., Dalia, G. and Pierre, M. (2018). "Identifying the Economic Impacts of Climate Change on Agriculture," Annual Review of Resource Economics, 10(1), 361-380.

Dang, N.A., Leonardelli, I. and A.A. Dipierri. (2016). Report on Migration, Environment and Climate Change: Vietnam National Reviews. Geneva: International Organization on Migration.

Dapice, D. and T.X. Vo (2012). "The Mekong Delta: Rural Development Meets the Environment-Systemic Challenges and Possible Solutions," Journal of Macromarketing, 32(1), 147-149.

Davies, M., Béné, C., Arnall, A., Tanner, T., Newsham, A. and Coirolo, C. (2013). "Promoting Resilient Livelihoods through Adaptive Social Protection: Lessons from 124 programmes in South Asia," Development Policy Review, 31(1), 27-58. 
Di Falco, S. and M. Veronesi (2013). "How can African agriculture adapt to climate change? A counterfactual analysis from Ethiopia," Land Economics, 89(4), 743-766.

Dong Thap Provincial People's Committee. (2016). Action Plan to Respond to Climate Change of Dong Thap Province. Dong Thap, Vietnam: Dong Thap Provincial People's Committee.

Dong Thap Provincial People's Committee. (2019a). The project: Sustainable Livelihoods in the Mekong River Delta (MD-ICRSL). Subproject: Enhancing the capacity of flood release and developing sustainable livelihoods and climate adaptation in the Plain of Reed region (in northern districts of Dong Thap province). Dong Thap: Dong Thap Provincial People's Committee.

Dong Thap Provincial People's Committee. (2019b). Report of Environmental and Social Impact Assessment, NOL version of the World Bank according to Official Letter No. 596/CPO-ICRSL, dated May 22, 2019. Dong Thap, Vietnam: Dong Thap Provincial People's Committee.

Epstein, G., Sandberg, A. and I. Bay-Larsen. (2014). Institutions and adaptation processes: A social-ecological system approach for the study of adaptation to climate change. Workshop in Political Theory and Policy Analysis. Indianapolis: Indiana University.

Fankhauser, S. (2017). “Adaptation to climate change," Annual Reviews of Resource Economics, 9(1), 209-230.

FAO. 2012. Climate Change Adaptation and Mitigation: Challenges and Opportunities in the Food sector. Rome: FAO.

Garmestani, A., Craig, R.K., Gilissen, H.K., McDonald, J., Soininen, N., van DoornHoekveld, W.J. and van Rijswick, H.F.M.W. (2019). "The Role of Social-Ecological Resilience in Coastal Zone Management: A Comparative Law Approach to Three Coastal Nations," Frontiers in Ecology and Evolution, 7(410), 1-14, doi: 10.3389/fevo.2019.00410.

Gorddard, J., Colloff, M.J., Wise, R.M., Ware, D. and M. Dunlop. (2016). "Values, rules and knowledge: Adaptation as change in the decision context," Journal of Environmental Science \& Policy, 57(1), 60-69.

Grosijean, G., Acworth, W., Flachsland, C. and Marschinski, R. (2016). "After Monetary Policy, Climate Policy: Is Delegation the Key to EU ETS Reform," Climate Policy, 16(1) 1-25, DOI: 10.1080/14693062.2014.965657

Hoang, P.L., Biesbroek, R., Pham, V.D.T., Kummu, M., Vliet, M.T.H., Leemans, R., Kabat, P. and Ludwig, F. (2018). "Managing flood risks in the Mekong Delta: How to address emerging challenges under climate changes and socioeconomic developments," Ambio, 47(1), 635-649. https://doi.org/10.1007/s13280-017-1009-4

Institute of Southern Construction Planning. (2014). Construction planning of Dong Thap province to 2030, vision to 2050. Dong Thap, Vietnam: Dong Thap Provincial People's Committee.

Institute of Water Resource Planning. (2016). Topographic map of Dong Thap Muoi sub-region, Report of the project on sustainable development linkage in Dong Thap Muoi region to 2020, vision to 2030. Dong Thap, Vietnam: Dong Thap Provincial People's Committee.

IPCC. (2012). "Managing the Risks of Extreme Events and Disasters to Advance Climate Change Adaptation." A special Report of Working Groups I and II of the Intergovernmental panel on Climate Change. Cambridge: CUP.

IPCC. (2014). "Climate Change 2014: Synthesis Report," in R.K. Pachauri and L.A. Meyer (eds.), Contribution of Working Groups I, II and III to the Fifth Assessment Report of the Intergovernmental Panel on Climate Change. Geneva: IPCC.

Jeetendra, P. A., Tek, B.S., Dil, B.R., Timothy, J.K., Sumona, S., Jat, M. L. and Clare, M.S. (2020). "Major Climate risks and Adaptation Strategies of Smallholder Farmers

XLinguae, Volume 15 Issue 1, January 2022, ISSN 1337-8384, eISSN 2453-711X 
in Coastal Bangladesh," Environmental Management, 66(1), 105-120. https://doi.org/10.1007/s00267-020-01291-8.

Juan, R., Malmborg, K., Gordon, L., Brauman, K. and F. DeClerck. (2020). "Mapping Social-Ecological Systems archetypes," Environmental Research Letters, 15, 034017.

Klein, R.J.T., Huq, S., Denton, F., Downing, T.E., Richels, R.G., Robinson, J.B. and Toth, F.L. (2007). "Inter-relationships between adaptation and mitigation. Climate Change 2007," in M.L. Parry, O.F. Canziani, J.P. Palutikof, P.J. van der Linden and C.E. Hanson (eds.), Impacts, Adaptation and Vulnerability. Contribution of Working Group II to the Fourth Assessment Report of the Intergovernmental Panel on Climate Change," Cambridge: Cambridge University Press, 745-777.

Le, A.T. and C. Suppakorn (2011). Climate Change in the Mekong River Delta and Key Concerns on Future Climate Threats. Geneva: Springer. DOI: 10.1007/978-94007-0934-8 12. Online ISBN 978-94-007-0934-8

McGinnis, M.D. and E. Ostrom (2014). "Social-ecological system framework: Initial changes and continuing challenges," Ecology and Society, 19(2), 30. http://dx.doi.org/10.5751/ES-06387-190230.

Mertz, O., Halsnæs, K., Olesen, J.E. and Rasmussen, K. (2009). "Adaptation to Climate Change in Developing Countries," Environmental Management, 43(1), 743752. DOI 10.1007/s00267-008-9259-3.

Michael, J.M., Jerry, J. V., Andreas, R. and A.D. Esther. (2014). Understanding Society and Natural Resources. New York: Springer ISBN 978-94-017-8958-5.

Millner A. and S. Dietzs (2015). "Adaptation to climate change and economic growth in developing countries," Environment and Development Economics, 20(3), 380-406.

Mimura, N., Pulwarty, R.S., Duc, D.M., Elshinnawy, I., Redsteer, M.H., Huang, H.Q., Nkem, J.N. and Rodriguez, R.A. (2014). "Adaptation planning and implementation," in Climate Change 2014: Impacts, Adaptation, and Vulnerability. Part A: Global and Sectoral Aspects. Contribution of Working Group II to the Fifth Assessment Report of the Intergovernmental Panel on Climate Change. Cambridge, UK and New York, USA: Cambridge University Press, 869-898.

Ministry of Natural Resource and Environment (2019a). Climate change and sea level rise scenarios in the Mekong River Delta. Impact assessment and proposing solutions. Report on Workshop on 10 years of implementation of the National Target Program on New Rural Development Southeast and Mekong River Delta. Bac Lieu, Science Publisher.

Ministry of Natural Resource and Environment (2019b). Management of water resources, floods, saline intrusion, response to subsidence and landslides in the Mekong Delta. Conference proceedings on evaluation of two-year implementation of Government's resolution on climate resilient and sustainable development of the Mekong Delta of Vietnam. Hanoi: Dan Tri Publishing House. ISBN 978-604-889850-2.

Nguyen, C.T., Ha, H.N. and T.T. Tran (2020). "Climate change adaptation policies of Vietnam in the Mekong Delta," The Russian Journal of Vietnamese Studies, 2(3), 5065. ISSN 2618-9453, DOI: 10.24411/2618-9453-2020-10023.

Nicholls, R.J., Hutton, C.W., Adger, W.N., Hanson, S.E., Rahman, Md.M. and Salehin, M. (2018). "Ecosystem Services for Well-Being in Deltas," Environmental Management, 66(1) 43-81. https://doi.org/10.1007/978-3-319-71093-8_22.

Niederhafner, S. (2014). "The Korean Energy and GHG Target Management System: An Alternative to Kyoto-Protocol Emissions Trading Systems?," in TEMEP Discussion Paper No. 2014: 118. Technology Management, Economics, and Policy Program. Seoul: College of Engineering, Seoul National University.

Nives, D. and P. Aseem (2018). "The Politics of Climate Change Adaptation," Annual Review of Environment and Resources, 43(1), 317-341.

Ostrom, E. (2009). "A general framework for analyzing sustainability of socialecological systems," Science, 325(5939), 419-42. 
Petrosillo, I., Aretano, R. and Zurlini, G. (2015). Socioecological Systems, Reference Module in Earth Systems and Environmental Sciences. Amsterdam: Elsevier. Doi: 10.1016/B978-0-12-409548-9.09518-X.

Susmita, D., Benoit, L., Craig, M., David, W. and Jianping, Y (2007). The Impact of Sea Level Rise on Developing Countries: A Comparative Analysis. World Bank Policy Research, Working Paper 4136, February 2007. New York: World Bank.

Tran, T.T. (2015). Geographical basis for spatial organization of economic development and environmental protection for Mong Cai border gate city, Quang Ninh province. [Dissertation]. Hanoi: Vietnam National University.

Tran, T.T. and H.N. Ha (2020). "Approach of ecological-social region to adapt to climate change," Journal of Sociology, 4(1), 93-104. ISSN 2615-9163.

Tran, T.T., Dao, H.T., Ha, H.N. and M.H. Pham. (2021). "Proactively adapting to climate change from a socio-ecological approach," in Proceedings of Vietnam National Conference on Geography Science, Vietnam. Hanoi: Thanh Nien Publishing House.

UNDP. (2008). Adaptation to Climate Change: The new challenge for development in the developing world. Copenhagen at the 15th Conference of the Parties. Copenhagen: UNDP.

USAID/UNDP. (2016). Economics of climate change adaptation: Agriculture sector analysis for Viet Nam. USAID Climate Change Adaptation Project Preparation Facility for Asian and the Pacific/United Nations Development Programme. Bangkok: USAID/UNDP

Vietnam-Netherlands Mekong Delta Masterplan Project (2013). Mekong Delta Plan: Long-term vision and strategy for a safe, prosperous and sustainable delta. Hanoi: Science Publisher.

Watkiss, P. and R. Klein (2019). Long-term Strategies in a Changing Climate. Berlin: GIZ.

WB. (2016). Shock Waves: Managing the Impacts of Climate Change on Poverty. Washington D.C.: World Bank.

WB-ADB. (2018). Climate Risk Country Profile: Vietnam. New Yor: WB, 2-5.

Words: 7409

Characters: 51166 (28,43 standard pages)

Tuyet Thi Tran

Institute of Human Geography

Vietnam Academy of Social Sciences

No 1 Lieu Giai Street, Hanoi

Vietnam

trantuyet.iesd@gmail.com

Ngoc Huy Ha

Vietnam Institute of Economics

Vietnam Academy of Social Sciences

No 1 Lieu Giai Street, Hanoi

Vietnam

huyngoc47q1@gmail.com

Tuan Hoang Dao

Institute of Human Geography

Vietnam Academy of Social Sciences

No 1 Lieu Giai Street, Hanoi

Vietnam

XLinguae, Volume 15 Issue 1, January 2022, ISSN 1337-8384, eISSN 2453-711X 
daohoangtuagn58@gmail.com

Xuan Thi Tran

Graduate Academy of Social Sciences

Vietnam Academy of Social Sciences

No 477 Nguyen Trai Road, Hanoi

Vietnam

tranxuan.gass@gmail.com 